Jurnal BASTRA (Bahasa dan Sastra) : http://ojs.uho.ac.id/index.php/BASTRA

\title{
SIKAP SISWA TERHADAP PEMBELAJARAN BAHASA INDONESIA DI KELAS VIII SMP NEGERI 15 KONSEL
}

\author{
OLEH \\ Sasmita $^{1}$, Nurlaela ${ }^{2}$ dan Amirudin Rahim ${ }^{3}$ \\ ${ }^{1}$ Alumni Jurusan Pend. Bahasa dan Sastra Indonesia, ${ }^{2,3}$ Dosen Jurusan \\ Pendidikan Bahasa dan Sastra Indonesia, Fakultas Keguruan dan Ilmu \\ Pendidikan Universitas Halu Oleo
}

\begin{abstract}
ABSTRAK
Tujuan penelitian ini adalah untuk mendeskripsikan sikap siswa terhadap pembelajaran bahasa Indonesia di kelas VIII SMP Negeri 15 Konsel. Jenis penelitian yang digunakan yaitu penelitian lapangan sebab peneliti turun langsung ke lokasi penelitian (sekolah). Metode yang digunakan yaitu metode deskriptif kuantitatif. Data dikumpulkan melalui angket berstruktur skala likert disertai observasi. Skala ini dikemas dengan menampilkan empat pilihan jawaban yaitu sangat setuju, setuju, tidak setuju dan sangat tidak setuju. Hasil penelitian menunjukan persentase sikap sangat setuju 96\%, setuju 4\%, tidak setuju 0\%, dan sangat tidak setuju 0\%. Sikap siswa terhadap pembelajaran bahasa Indonesia di kelas VIII SMP Negeri 15 Konsel berada pada kategori sangat setuju, sehingga dapat disimpulkan bahwa siswa kelas VIII SMP Negeri 15 Konsel bersikap positif terhadap pembelajaran bahasa Indonesia.
\end{abstract}

Kata Kunci: sikap siswa, pembelajaran 


\section{PENDAHULUAN}

\subsection{Latar Belakang}

Pendidikan merupakan kegiatan seseorang atau sekelompok orang dalam upaya mendewasakan manusia melalui program pengajaran, pelatihan, dan bimbingan. Pendidikan meliputi kegiatan berpikir dan bertindak. Pendidikan dapat dikatakan sebagai usaha sadar yang dilaksanakan secara terencana. Pendidikan merupakan kebutuhan mutlak yang harus dipenuhi. Tanpa pendidikan, manusia akan memiliki kendala dalam hidup untuk berkembang.

Pada hakikatnya tujuan pendidikan adalah untuk menjadikan manusia berpendidikan. Tugas utama pendidikan yaitu menanamkan keyakinan pada diri seseorang serta mengembangkan potensi-potensi yang ada dalam diri seseorang. Potensipotensi tersebut diharapkan dapat tumbuh dan berkembang sesuai dengan nilai-nilai yang ada di dalam masyarakat dan bangsa. Sebagaimana fungsi pendidikan yang tertera dalam UU No. 20 Tahun 2003 tentang Sisdiknas yaitu untuk mengembangkan kemampuan dan membentuk watak, kreatiafitas serta menjadi warga yang demokratis dan bertanggung jawab.

Warga yang demokratis dan bertanggung jawab berarti sadar akan perannya dalam kehidupan berbangsa dan bernegara yaitu mampu meningkatkan dan mengembangkan tanggung jawab moral dan mampu mngembangkan sikap bertanggung jawab terhadap kehidupan pribadi dan sosial serta mengutamakan persamaan hak dan kewajiban serta perlakuan yang sama bagi semua warga negara.

Bahasa Indonesia sebagai bahasa nasional dan bahasa negara harus terus dibina dan dikembangkan agar menjadi bahasa modern, yakni bahasa yang sanggup mengembangkan fungsinya sebagai sarana komunikasi dalam berbagai segi kehidupan.

Dalam usaha membina dan mengembangkan bahasa Indonesia, pemerintah mendirikan Badan Pengembangan dan Pembinaan Bahasa yang bertugas melaksanakan pengembangan, pembinaan, dan pelindungan terhadap bahasa Indonesia. Selain itu, pemerintah juga menjadikan bahasa Indonesia sebagai salah satu bidang studi wajib yang harus diikuti oleh siswa, dari sekolah dasar hingga perguruan tinggi.

Tujuan pembinaan dan pengembangan bahasa Indonesia melalui pendidikan formal adalah agar siswa memiliki keterampilan berbahasa lisan maupun tulis, siswa juga diharapkan mampu memiliki jati diri yang tetap. Sebagai siswa, diharapkan memiliki sikap yang baik, yang harus ditanamkan sejak dini. Hal ini bertujuan agar siswa mampu mengembangkan pikiran dan mempersiapkan diri untuk menghadapi realitas.

Pada kenyataannya, pelaksanaan pembelajaran bahasa Indonesia di dalam kelas sering terjadi berbagai masalah seperti siswa kurang memahami materi pembelajaran, siswa kurang semangat mengikuti proses pembelajaran, siswa mengantuk dalam proses pembelajaran, dan lain sebagainya. Masalah-masalah tersebut dapat berasal dari peserta didik maupun komponen lainnya. Bahkan masalah yang muncul di dalam kelas bersifat kompleks, sehingga menghambat terlaksananya kegiatan belajar.

Permasalahan yang muncul di dalam kelas memang sudah biasa terjadi. Namun, permasalahan tersebut tidak boleh dibiarkan begitu saja, 
karena sekecil apapun permasalahan dalam kelas dapat mengganggu berlangsungnya proses belajar mengajar. Efek dari permasalahan yang muncul dapat berupa terhambatnya kegiatan belajar, pembelajaran menjadi kurang efektif, bahkan peserta didik dapat mengalami kehilangan konsentrasi. Dengan demikian, tujuan pembelajaran tidak dapat tercapai, sehingga dapat berpengaruh pada prestasi belajar peserta didik.

Keberhasilan pembelajaran
bahasa Indonesia tidak dapat dipisahkan dari berbagai faktor yang mempengaruhinya, yakni faktor yang berasal dari diri siswa, faktor lingkungan siswa, faktor materi, dan lain sebagainya. Salah satu faktor yang memegang peranan penting adalah faktor yang berasal dari diri siswa yang biasa disebut karakteristik siswa. Karakteristik siswa dalam pembelajaran meliputi motivasi, minat, sikap, bakat, kecerdasan dan lain sebagainya.

Sikap merupakan respons terhadap sesuatu atau objek. Hal ini berdasarkan pandangan Donsu (2017: 183) yang menyatakan bahwa sikap (attitude) adalah respons tertutup seseorang terhadap suatu stimulus atau objek, baik yang bersifat internal maupun eksternal, sehingga manifestasinya tidak dapat langsung dilihat, tetapi hanya dapat ditafsirkan terlebih dahulu dari perilaku yang tertutup tersebut. Sikap juga dapat diartikan sebagai pikiran atau perasaan yang menghasilkan tingkah laku sesuai dengan respons terhadap suatu hal, sehingga sikap dapat dikatakan sebagai penentu tingkah laku manusia. Sebagai respons, sikap selalu berhubungan dengan dua hal yaitu suka atau tidak suka.
Sikap mempunyai dua arah yaitu positif dan negatif. Mengacu pada adanya faktor perbedaan antara individu, seperti perbedaan pengalaman, latar belakang, ekonomi dan lain sebagainya, maka sikap yang muncul terhadap satu objek akan berbeda-beda pada setiap individu.

Dalam pembelajaran bahasa Indonesia, sikap yang muncul pada setiap siswa akan berbeda-beda terhadap proses belajar mengajar. Sikap tersebut akan berpengaruh pada hasil belajar siswa. Oleh karena itu, penelitian tentang sikap siswa terhadap pembelajaran bahasa Indonesia penting untuk diteliti. Selain itu, Penelitian tentang sikap siswa terhadap pembelajaran bahasa Indonesia belum pernah dilakukan di SMP Negeri 15 Konsel.

\subsection{Rumusan Masalah}

Berdasarkan latar belakang, masalah dalam penelitian ini adalah bagaimanakah sikap siswa terhadap pembelajaran bahasa Indonesia di kelas VIII SMP Negeri 15 Konsel?

\subsection{Tujuan Penelitian}

Tujuan dari penelitian ini adalah untuk mendeskripsikan sikap siswa terhadap pembelajaran bahasa Indonesia di kelas VIII SMP Negeri 15 Konsel.

\subsection{Manfaat Penelitian}

Manfaat yang diharapkan dalam penelitian ini adalah sebagai berikut.

1. Sebagai bahan refleksi dan informasi bagi guru dalam mengembangkan pembelajaran bahasa Indonesia sehingga mutu pendidikan dan pengajaran bahasa Indonesia dapat ditingkatkan.

2. Sebagai wadah bagi siswa untuk menyatakan sikapnya terhadap pembelajaran bahasa Indonesia. 
3. Sebagai bahan informasi dan rujukan bagi penelitian selanjutnya, terutama penelitian yang berkaita dengan sikap.

\subsection{Batasan Operasional}

Batasan operasional yang digunakan dalam penelitian ini adalah sebagai berikut.

1. Sikap adalah respons seseorang terhadap sesuatu atau objek. Sikap yang dimaksud dalam penelitian ini adalah sikap siswa terhadap pembelajaran bahasa Indonesia di kelas VIII SMP Negeri 15 Konsel yang meliputi sikap siswa terhadap guru, sikap siswa terhadap diri sendiri, sikap siswa terhadap materi pembelajaran, sikap siswa terhadap metode pembelajaran, dan sikap siswa terhadap media pembelajaran.

2. Pembelajaran adalah proses belajar mengajar yang sistematis dan bersifat interaktif dan komunikatif antara pendidik dan peserta didik. Pembelajaran yang dimaksud dalam penelitian ini adalah proses belajar mengajar bahasa Indonesia di kelas VIII SMP Negeri 15 Konsel.

\section{KAJIAN PUSTAKA \\ 2.1 Sikap Siswa}

Sikap merupakan keadaan siap untuk bertindak. Keadaan siap ini ditafsirkan sebagai suatu kecenderungan potensial untuk bereaksi apabila individu dihadapkan pada suatu stimulus atau rangsangan yang menghendaki adanya respons. Hal ini berdasarkan pandangan Arifin (2016: 159) yang menyatakan bahwa sikap merupakan suatu kecenderungan tingkah laku untuk berbuat sesuatu dengan cara, metode, teknik, dan pola tertentu terhadap dunia sekitarnya, baik berupa orang-orang maupun objek-objek tertentu. Dalam Kamus Besar Bahasa Indonesia (2008: 1303) kata sikap berarti tokoh atau bentuk tubuh, cara berdiri (tegak, teratur, atau dipersiapkan untuk bertindak).

Sikap merupakan kecenderungan yang relatif untuk bereaksi dengan cara baik atau buruk terhadap orang atau barang tertentu. Sikap mengacu kepada perbuatan atau perilaku seseorang, tetapi tidak semua perbuatan identik dengan sikap. Perbuatan seseorang mungkin saja bertentangan dengan sikapnya.

Setiap orang mempunyai sikap yang berbeda terhadap suatu objek. Hal ini disebabkan oleh berbagai faktor yang ada pada individu masingmasing seperti perbedaan dalam bakat, minat, pengetahuan, intensitas perasaan dan juga situasi lingkungan.

Sikap bermula dari perasaan suka atau tidak suka terhadap suatu hal. Hal ini sejalan dengan pendapat Jihad (2013: 102) yang menyatakan bahwa sikap bermula dari perasaan (suka atau tidak suka) yang berkaitan dengan kecenderungan seseorang dalam merespons sesuatu/objek.

Sikap tidak dapat dilihat secara langsung, karena bersifat internal atau keadaan yang masih ada dalam diri seseorang. Hal ini berdasarkan pandangan Donsu (2017: 183) yang menyatakan bahwa sikap (attitude) adalah respons tertutup seseorang terhadap suatu stimulus atau objek, baik yang bersifat internal maupun eksternal, sehingga manifestasinya tidak dapat langsung dilihat, tetapi hanya dapat ditafsirkan terlebih dahulu dari perilaku yang tertutup tersebut. Sikap mempunyai dua arah yaitu positif dan negatif. Mengacu pada adanya faktor perbedaan antara individu, seperti perbedaan 
pengalaman, latar belakang, ekonomi dan lain sebagainya, maka sikap yang muncul terhadap satu objek akan berbeda-beda pada setiap individu.

\section{Berdasarkan}

pandangan beberapa ahli, dapat disimpulkan bahwa sikap adalah respons sesorang terhadap sesuatu atau objek, baik yang bersifat internal maupun eksternal. Sebagai respons sikap selalu berhubungan dengan dua hal yaitu suka atau tidak suka.

Dalam pembelajaran, sikap siswa dapat diartikan sebagai respons siswa terhadap pembelajaran.

\subsection{Karakteristik Sikap}

Sikap mempunyai beberapa karakteristik yaitu sikap mempunyai arah, intensitas, keluasan, konsisten, dan spontanitas (Suharyat, 2009: 6).

1. Arah maksudnya arah yang positif atau negatif.

2. Intensitas maksudnya kekuatan sikap itu sendiri, setiap orang belum tentu mempunyai kekuatan sikap yang sama. Orang yang sama-sama mempunyai sikap positif terhadap sesuatu, tidak menutup kemungkinan adanya perbedaan kekuatan sikapnya, yang satu bisa jadi positif dan yang satu bisa jadi lebih positif.

3. Keluasan sikap meliputi cakupan aspek objek sikap yang disetujui atau tidak disetujui seseorang.

4. Konsistensi adalah kesesuaian antara pernyataan sikap dengan respon, atau tidak adanya kebimbangan.

5. Spontanitas yaitu sejauh mana kesiapan subjek untuk menyatakan sikapnya secara spontan. Suatu sikap dikatakan mempunyai spontanitas yang tinggi, apabila sikap dinyatakan tanpa perlu pengungkapan atau desakan agar subjek menyatakan sikapnya.

\subsection{Komponen Sikap}

Sikap terdiri atas tiga komponen yaitu afektif, kognitif, dan konatif Komponen afektif adalah perasaan yang dimiliki oleh seseorang atau penilaiannya terhadap sesuatu objek. Komponen kognitif adalah kepercayaan atau keyakinan seseorang mengenai objek. Adapun komponen konatif adalah kecenderungan untuk berperilaku atau berbuat dengan caracara tertentu berkenaan dengan kehadiran objek sikap (Jihad dan Haris, 2013 : 102).

\subsection{Faktor Penentu Sikap}

Terdapat empat faktor penentu sikap seseorang. Faktor tersebut meliputi faktor fisiologis, faktor kerangka acuan, faktor sosial, dan faktor pengalaman langsung terhadap objek (Bimo Walgilo dalam Donsu, 2017: 169).

1. Faktor fisiologis

Sikap ini ditentukan oleh faktor usia dan kesehatan seseorang. Misalnya orang yang dewasa tentunya memiliki kecenderungan untuk bersikap lebih dewasa.

2. Faktor kerangka acuan

Sikap ini lebih mengacu pada objek, sikap inilah yang akan menentukan seseorang bersikap negatif atau positif terhadap objek.

3. Faktor komuniaksi sosial.

Faktor ini tergantung dari informasi yang seseorang terima. Jika informasi yang diterima ditangkap secara negatif, maka sikapnya pun akan negatif. Sebaliknya, jika informasi yang diterima ditangkap secara positif, maka sikapnya pun akan positif.

4. Faktor pengalaman langsung terhadap objek

Faktor pengalaman langsung dipengaruhi oleh pengalaman langsung terhadap objek sikap. 


\subsection{Indiktor Sikap}

Berikut adalah indikator atau ciri-ciri sikap (Donsu, 2017: 171).

1. Sikap muncul karena proses belajar, sehingga berdasarkan latihan dan pengkondisian.

2. Sifat sikap berubah-ubah, sehingga menyebabkan orang mempelajari perilaku satu sama lain.

3. Sikap berdiri saling berhubungan dengan objek sikap.

4. Sikap tertuju pada satu objek dan banyak objek.

5. Sikap berjalan dalam waktu lama maupun sebentar.

6. Sikap memiliki rasa dan motivasi, dua hal inilah yang membedakan dengan pengetahuan.

Pada prinsipnya, dalam interaksi sosial semua manusia melakukan enam hal tersebut baik disadari ataupun tidak disadari.

\subsection{Manfaat Sikap}

Ada empat manfaat sikap yang dipaparkan oleh Baron dan Byrne dalam Donsu (2017: 167), antara lain sebagai berikut.

\section{Sebagai Skema}

Skema dapat membantu orang untuk menginterprestasi (menilai) segala bentuk yang masuk. Hal ini berkaitan untuk membantu pembentukan persepsi. Tanpa skema, persepsi sulit untuk menerjemahkan dan mengambil kesimpulan. Oleh karena itu, sikap berfungsi sebagai upaya seseorang untuk memahami dunia sosial.

\section{Knowledge Function}

Skema memang memudahkan seseorang memahami lingkungan sosialnya. Namu tanpa knowledge function (pengetahuan) skema dapat menjebak. Karena dengan sikap yang disertai pengetahuan akan memperkuat perilaku yang memiliki self esteem (ekspresi diri) dan self identity (identitas diri).

\section{Sebagai self esteem}

Individu yang sehat adalah individu yang memiliki self esteem. Dengan adanya self esteem inilah yang meningkatkan harga diri seseorang. Seseorang yang tidak memiliki kepercayaan diri yang cukup, terkadang membuat seseorang harga dirinya rendah, tidak percaya diri dan tidak maksimal. Selain self esteem sikap mempertahankan ego terkadang juga perlu. Sikap mempertahankan ego dalam hal ini adalah mempertahankan diri dari informasi negatif dan merugikan diri.

\section{Motivasi Impresi}

Motivasi impresi adalah motivasi seseorang untuk menimbulkan kebahagiaan dan power (semangat) terhadap orang lain. Prinsip impresi yaitu adanya sebab akibat yang mempengaruhi dan dipengaruhi. Semakin besar motivasi impresi yang kuat terhadap orang lain, semakin kuat pula individu mengaplikasikan dalam bentuk sikap.

\subsection{Penilaian Sikap}

Secara umum, sikap dapat dinilai secara langsung dan tidak langsung (Donsu, 2017: 172).

\subsubsection{Secara Langsung}

Pengukuran sikap secara langsung dilakukan dengan cara mengajukan pertanyaan. Adapun beberapa jenis pengukuran sikap yang termasuk pengukuran sikap secara langsung, yaitu dengan cata terstruktur dan tidak terstruktur.

\subsubsection{Skala Terstruktur}

Skala terstruktur selain secara tertulis, juga bisa dengan mengajukan pertanyaan yang tersusun begitu rapi. Adapun beberapa nama alat tes pengukur sikap yang disebut skala adalah sebagai berikut. 
a. Skala Bogardus

Skala bogardus adalah skala untuk mengetahui sejauh mana sikap seseorang. Berdasarkan jarak sosialnya seperti yang dirasakan. Dalam interaksi sosial dengan lingkungan sekitar, sering terjadi jarak sosial, penyebabnya bermacam-macam, bisa disebabkan karena faktor usia, ras, agama, dan lain sebagainya.

b. Skala Thurston

Skala yang digunakan untuk mengukur sikap seseorang terhadap pengaruh like-dislike (suka atau tidak suka). Penggunaan skala Thurston menggunakan metode equal-appearing intervals yang telah disusun sedemikian rupa. Penyusunannya disebut semacam range bawah ke atas, dari yang menyenangkan sampai yang tidak menyenangkan.

c. Skala likert

Skala ini dikemas dengan menampilkan lima pilihan jawaban. Pertanyaan yang diajukan pun berupa pernyataan. Tester biasanya disuruh dengan memilih jawaban yang sudah disediakan. Bentuk pilihan jawabanya pun sama dengan jawaban sebelumnya, yaitu sangat setuju, setuju, ragu-ragu, tidak setuju, dan sangat tidak setuju.

\section{7..2 Skala tidak Terstruktur}

Penilaian sikap paling sederhana dan tanpa persiapan yang ribet adalah mengunakan skala tidak terstruktur. Penilaian ini dilakukan hanya dengan wawancara, tetapi juga melakukan pengamatan secara langsung dan melakukan survei.

\subsubsection{Secara tidak Langsung}

Mengukur sikap secara tidak langsung dapat menggunakan skala semantik-diferensial. Cara pengukuran sikap ini lebih banyak digunakan dalam menilai seseorang. Penggagas skala ini adalah Charles E. Osgood.

\subsection{Pembelajaran}

Pembelajaran merupakan aspek utama dalam pendidikan karena pengalaman belajar akan menentukan pembentukan kemampuan peserta didik, yang selanjutnya akan menentukan mutu pendidikan. Inti pembelajaran itu adalah sebagai suatu proses perubahan tingkah laku pada diri individu berkat adanya interaksi antara individu dan individu dengan lingkungannya (Asril, 2015: 1).

Pembelajaran pada hakikanya adalah suatu proses, yaitu proses mengatur dan mengorganisasi lingkungan yang ada di sekitar peserta didik sehingga dapat mendorong peserta didik agar dapat melakukan proses belajar.

Belajar menunjukkan aktivitas yang dilakukan oleh seorang secara sadar. Aktivitas ini menunjukkan keaktifan seseorang dalam melakukan aspek mental yang memungkinkan terjadinya perubahan pada dirinya. Dengan demikian, dapat dipahami bahwa suatu kegiatan belajar dapat dikatakan baik apabila intensitas jasmani dan mental seseorang semakin tinggi. Sebaliknya, meskipun seseorang dikatakan belajar, tetapi keaktifan jasmani dan mentalnya rendah berarti kegiatan belajar tersebut tidak secara nyata dipahami bahwa dirinya sedang melakukan suatu kegiatan yatitu proses belajar.

\subsection{Komponen Pembelajaran}

Kompenen dari sebuah pembelajaran adalah guru, isi atau materi pembelajaran, dan siswa. Interaksi antara tiga komponen utama melibatkan metode pembelajaran, media pembelajaran, dan penataan lingkungan tempat belajar, sehingga 
tercipta situasi pembelajaran yang memungkinkan terciptanya tujuan yang telah direncanakan sebelumnya (Kurniasih, 2017: 22).

\subsubsection{Guru}

Guru sebagai pelaku utama dalam penerapan program pendidikan di sekolah memiliki peranan yang sangat strategis untuk mencapai tujuan pendidikan yang diharapkan. Oleh karena itu, guru dipandang sebagai faktor utama yang menentukan pencapaian mutu atau prestasi belajar. Hal ini berdasarkan pendapat Asmani (2009: 26) yang menyatakan bahwa dalam bidang pendidikan, pemegang kunci dalam pengembangan daya kreativitas anak adalah guru.

Dengan peranan yang begitu penting, guru dituntut untuk memiliki pemahaman dan kemampuan secara komprehensif terhadap kompetensinya sebagai pendidik. Seorang guru harus kreatif agar dapat membantu peserta didik untuk mengembangkan kreativitasnya, karena untuk meningkatkan kualitas belajar peserta didik dibutuhkan suatu proses kreatif dalam pembelajaran. Proses kreatif yang dimaksud dalam pembelajaran yaitu upaya-upaya penting yang dilakukan guru untuk mendayagunakan potensi kognitif dan afektif dari siswa secara optimal. Guru harus selalu mengomunikasikan ideide yang baru kepada peserta didik.

Guru profesional dituntut terampil mengemas pembelajaran dan terampil dalam mengajar tidak hanya untuk manyajikan materi pelajaran, tetapi juga dituntut untuk memiliki pendekatan pembelajaran yang sesuai dengan tujuan pembelajaran dan menguasai serta memahami materi yang akan diajarkan agar dengan cara demikian peserta didik akan benar- benar memahami apa yang akan diajarkan.

Salah satu kompetensi yang harus dimiliki oleh guru adalah performance (kinerja), yaitu seperangkat perilaku nyata yang ditunjukkan sesorang pada waktu melaksanakan tugas sesuai dengan profesi dan keahlian. Sementara kinerja (performance) guru dapat diartikan sebagai seperangkat perilaku guru yang terkait dengan gaya mengajar, kemampuan berinterkasi dengan siswa, dan karakteristik pribadinya yang ditampilkan pada waktu melakasanakan tugas profesionalnya sebagai pendidik (Yusuf, 2016: 140).

\subsubsection{Siswa}

Siswa atau peserta didik merupakan pusat dari kegiatan pembelajaran. Kurniasih (2017: 26) menyatakan bahwa kondisi serta jenjang pndidikan siswa haruslah jadi pertimbangan pertama oleh para guru dan pengajar. proses pembelajaran pada hakikatnya diarahkan untuk membelajarakan siswa agar mencapai tujuan yang telah ditentukan. Dalam diri siswa terdapat potensi yang siap untuk berkembang. Siswa memiliki kebutuhan, minat, emosi dan lain sebagainya. Setiap siswa memiliki perbedaan satu sama lain, karena masing-maing berkembang menurut pola pikir dan cara sendiri.

Siswa merupakan seorang pelajar atau murid yang sedang duduk dibangku SD (Sekolah Dasar), SMP (Sekolah Menengah Pertama) dan SMA (Sekolah Menengah Atas). Siswa merupakan orang yang secara resmi terdaftar di suatu lembaga pendidikan untuk mengikuti pelajaran di dunia pendidikan. siswa merupakan komponen masukan dalam sistem pendidikan, yang selanjutnya diproses dalam proses pendidikan, sehingga 
menjadi manusia yang berkualitas sesuai dengan tujuan pendidikan nasional. Sebagai suatu komponen pendidikan, siswa dapat ditinjau dari pendekatan pendekatan sosial, pendekatan psikologis, dan pendekatan edukatif/pedagogis.

\subsubsection{Materi Pembelajaran}

Materi pmbelajaran adalah isi dari kurikulum. Hal ini berdasarkan pendapat Kurniasih (2017: 23) yang menyatakan bahwa pembelajaran pada dasarnya merupakan isi dari kurikulum, yakni mata pelajaran. atau bidang studi dengan sub topik dan rinciannya. Isi dari proses pembelajaran tercermin dalam materi pembelajaran yang dipelajari oleh siswa. Materi pelajaran adalah substansi yang akan disampaikan dalam proses belajar mengajar. Tanpa materi proses belajar mengajar tidak akan berjalan.

Materi pelajaran adalah subtansi yang akan disampaikan dalam pembelajaran. Tanpa ada materi pembelajaran proses belajar mengajar tidak akan berjalan. Oleh karena itu, guru yang akan mengajar harus menguasai materi pembelajaran yang akan disampaikan kepada peserta didik. Materi pembelajaran merupakan sumber belajar bagi siswa.

Pada umunya, aktivitas belajar peserta didik akan berkurang jika materi yang diberikan oleh guru tidak menarik. Materi pelajaran juga perlu dipilih dengan tepat agar dapat membantu siswa untuk mencapai standar kompetensi dan kompetensi dasar.

\subsubsection{Metode Pembelajaran}

Metode berarti cara atau teknik tertentu yang dianggap baik, dalam istilah metode pembelajaran dapat diartikan bahwa metode sebagai suatu kegiatan atau cara yang dilakukan untuk menunjang tercapainya tujuan pengajaran. Metode pembelajaran merupakan cara melakukan atau menyajikan, menguraikan, dan memberi latihan isi pelajaran kepada siswa untuk mencapai tujuan tertentu (Kurniasih, 2017: 25).

Metode pembelajaran berfungsi sebagai alat yang tetap untuk menambah partisipasi peserta didik dan menanamkan kepemimpinan dengan usaha menciptakan situasi mengajar dan belajar yang tepat. Dalam kegiatan belajar mengajar, metode sangat diperlukan oleh guru, penggunaan metode dapat dilakukan secara bervariasi sesuai dengan tujuan yang ingin dicapai.

Untuk memilih dan menggunakan metode pembelajaran yang paling tepat, maka perlu dihubungkan dengan fasilitas atau perlengkapan (media) yang digunakan dalam proses belajar mengajar.

Dalam memilih dan menggunakan metode pembelajaran harus memperhatikan beberapa ketentuan sehingga benar-benar fungsional. Berikut adalah beberapa ketentuan yang harus diperhatiakan (Asril: 5).

1. Bahan pelajaran yang akan diajarkan

2. Tujuan yang hendak dicapai

3. Gunakan metode yang dianggap paling tepat dan gunakan pula alat bantu yang sesuai

4. Hubungan antara metode dengan fasilitas, waktu, dan tempat.

Untuk melaksanakan pembelajaran perlu dipikirkan penggunaan metode yang tepat. Penggunaan metode pembelajaran tergantung pada kesesuaian metode pembelajaran, materi pelajaran, kemampuan guru, kondisi siswa, 
sumber atau fasilitas, situasi dan waktu.

Berbagai macam metode bisa digunakan dalam pembelajaran, mulai dari metode ceramah, tanya jawab, diskusi, resitasi, kerja kelompok, sisiodrama, pemecahan masalah, latihan, dan lain sebagainya.

Dalam proses interaksi edukatif kedudukan metode mengajar sangat penting, karena pengertian metode tidaklah hanya sekedar suatu cara, akan tetapi merupakan teknik di dalam proses penyampaian materi pengajaran. Oleh sebab itu, metode mengajar akan meliputi kemampuan mengorganisasi kegiatan dan teknik mengajar sampai kepada evaluasinya (Asril, 2015: 4).

\subsubsection{Media Pembelajaran}

Media adalah kata jamak yang berarti perantara. Secara definisi media merupakan suatu perangkat yang dapat menyalurkan informasi dari sumber ke penerima informasi (Yamin, 2009: 148). Media memegang peran penting dalam pembelajaran. Manfaat media dalam pembelajaran yaitu memperlancar proses interaksi antara guru dengan siswa, dalam hal ini membantu siswa belajar secara optimal.

Media merupakan alat bantu dalam proses belajar mengajar. Segala sesuatu yang dapat dipergunakan untuk merangsang pikiran, perasaan, perhatian dan kemampuan atau ketrampilan sehingga dapat mendorong terjadinya proses belajar. Media pembelajaran cukup penting sebagai salah satu komponen pembelajaran. Tanpa media, proses pembelajaran tidak akan berlangsung secara optimal. Media tidak terpisahkan dari proses belajar mengajar demi tercapainya tujuan pendidikan.
Media pembelajaran merupakan kegiatan yang melibatkan siswa dan guru dengan menggunakan berbagai sumber belajar baik di dalam maupun di luar kelas. Jenis media pembelajaran sangat beragam dan mempunyai kelebihan dan kelemahan masingmasing. Media pembelajaran yang tidak digunakan secara maksimal akan mempengaruhi hasil belajar siswa.

Dalam proses belajar mengajar, dua unsur yang sangat penting adalah metode mengajar dan media pengajaran, kedua aspek ini saling berkaitan. Pemilihan salah satu metode mengajar tentu akan mempengaruhi jenis media pengajaran yang sesuai, meskipun masih ada berbagai aspek lain yang harus diperhatikan dalam memilih media, antara lain tujuan pengajaran, jenis tugas dan respon yang diharapkan siswa dikuasai setelah pengajaran berlangsung, dan konteks pembelajaran termasuk karakteristik siswa. Oleh karena itu, dapat dikatakan bahwa salah satu fungsi utama media pengajaran adalah sebagai alat bantu mengajar yang turut mempengaruhi iklim, kondisi, dan lingkungan belajar yang ditata dan diciptakan oleh guru.

Media Pembelajaran mempunyai banyak jenis, ada media yang dapat dibuat oleh guru sendiri, ada media yang diproduksi pabrik, ada media yang sudah tersedia di lingkungan yang langsung dapat dimanfaatkan, dan ada pula media yang secara khusus sengaja dirancang untuk keperluan pembelajaran. Meskipun media banyak jenisnya. Namun media yang paling akrab dan hampir semua sekolah manfaatkan adalah media cetak (buku).

\subsection{Tujuan Pembelajaran}

Tujuan pembelajaran merupakan akumulasi dari konsep mengajar dan konsep belajar. Proses belajar terjadi 
apabila individu dihadapkan pada situasi di mana ia tidak dapat menyesuaikan diri dengan cara biasa, atau apabila ia harus mengatasi rintangan-rintangan yang mengganggu kegiatan yang diinginkan. Proses penyesuain diri mengatasi rintangan terjadi secara tidak sadar, tanpa pemikiran yang banyak terhadap apa yang dilakukan. Dalam hal ini pelajar mencoba melakukan kebiasaan atau tingkah laku yang telah terbentuk hingga ia mencapai respons yang memuakan.

Belajar adalah suatu proses perubahan tingkah laku yang berkesinambungan antara berbagai unsure dan berlangsung seumur hidup yang didorong oleh berbagai aspek seperti motivasi, emosional, sikap dan lain sebagainya yang pada akhirnya menghasilkan tingkah laku yang diharapkan. Unsur utama dalam belajara adalah individu sebagai peserta belajar, kebutuhan sebagai sumber pendorong, dan situasi belajar yang memungkinkan terjadinya kegiatan belajar.

\subsection{Konsep Pembelajaran Bahasa Indonesia}

Mata pelajaran bahasa Indonesia berorietasi pada pembelajaran bahasa, yakni belajar bahasa adalah belajar berkmunikasi. Oleh karena itu, pemibelajaran bahasa Indonesia diarahkan untuk meningkatkan kemampuan peserta didik untuk berkomunikasi dengan menggunakan bahasa yang baik dan benar, baik secara lisan maupun tulis, serta menimbulkan penghargaan terhadap hasil cipta bahasa Indonesia.

\subsection{Sikap Siswa dalam}

\section{Pembelajaran Bahasa}

Indonesia

Sikap selalu berhubungan dengan objek. Sikap timbul sebagai respons/reaksi terhadap suatu objek yang dapat berwujud penilaian atau tanggapan. Dengan demikian, sikap siswa dalam pembelajaran bahasa Indonesia dapat dilihat dari respons/reaksi mereka terhadap pembelajaran bahasa Indonesia. Respons tersebut akan berhubungan dengan dua hal yaitu suka atau tidak suka. Respons yang muncul pada setiap siswa harus dipahami oleh guru sebagai hal yang wajar, karena dalam pembelajaran guru hendaknya memberikan kesempatan kepada siswa untuk menyatakan sikap, minat, dan masalah-masalah yang mereka hadapi.

Sikap peserta didik terhadap pembelajaran bahasa Indonesia bisa positif dan bisa juga negatif atau netral. Namun, sikap yang diharapkan ada pada peserta didik adalah sikap positif, sehingga akan timbul minat untuk belajar dan prestasi belajar akan meningkat secara optimal.

\section{METODE DAN TEKNIK PENELITIAN}

\subsection{Jenis dan Metode Penelitian}

Jenis penelitian ini tergolong dalam penelitian lapangan sebab peneliti turun langsung ke lokasi penelitian (sekolah) untuk mengumpulkan data sesuai dengan masalah penelitian.

Metode yang digunakan dalam penelitian ini adalah metode deskriptif kuantitatif, yaitu menguraikan secara objektif hasil yang diperoleh dari sikap siswa terhadap pembelajaran bahasa Indonesia di kelas VIII SMP Negeri 15 Konsel. Data yang diperoleh diolah secara statistik.

\subsection{Populasi dan Sampel Penelitian}

\subsubsection{Populasi Penelitian}

Populasi yang digunakan dalam penelitian ini adalah seluruh siswa kelas VIII SMP Negeri 15 Konsel

282 |Jurnal BASTRA (Bahasa dan Sastra), Vol. 4 No. 3, Edisi Juli 2019/e-ISSN: 2503-3875/ http://ojs.uho.ac.id/index.php/BASTRA 
tahun ajaran 2018/2019 yang berjumlah 88 siswa yang terdiri atas siswa kelas VIII.1, VIII.2 dan VIII.3. Sifat populasi heterogen yaitu siswa memiliki sikap yang berbeda-beda terhadap pembelajaran.

Tabel 3.1

Populasi Siswa Kelas VIII SMP Negeri 15 Konsel

\begin{tabular}{|c|c|}
\hline Kelas & Jumlah \\
\hline VIII.1 & 26 \\
\hline VIII.2 & 31 \\
\hline VIII.3 & 31 \\
\hline Jumlah Siswa & 88 \\
\hline
\end{tabular}

\subsubsection{Sampel Penelitian}

Teknik sampel yang digunakan dalam penelitian ini adalah total sampling yaitu pengambilan sampel secara keseluruhan atau jumlah sampel sama dengan jumlah populasi. Sampel dalam pemelitian ini berjumlah 88 siswa.

\subsection{Instrumen Penelitian}

Instrumen yang digunakan dalam penelitian ini adalah angket yang berisi sejumlah pertanyaan mengenai sikap siswa terhadap pembelajaran bahasa Indonesia di kelas VIII SMP Negeri 15 Konsel. Angket yang digunakan adalah bentuk angket berstruktuk yaitu skala likert, skala ini dikemas dengan menggunakan empat alternatif jawaban, dibuat demikian agar semua responden perpendapat atau tidak bersikap netral. Selain itu, dilakukan juga observasi/pengamatan sebanyak dua kali pertemuan.

Angket yang disediakan dalam penelitian ini terdiri atas 25 butir soal, yaitu 5 butir soal yang berkaitan dengan guru, 5 butir soal yang berkaitan dengan diri sendiri, 5 butir soal yang berkaitan dengan materi pembelajaran, 5 butir yang berkaitan dengan metode pembelajaran, dan 5 butir yang berkaitan dengan media pembelajaran. Keseluruhan butir soal tersebut dilengkapi dengan alternatif jawaban, yaitu Sangat Setuju (SS), Setuju (S), Tidak Setuju (TS), Sangat Tidak Setuju (STS).

\subsection{Teknik Pengumpulan Data}

Teknik pengumpulan data dalam penelitian ini adalah menggunakan angket tentang sikap terhadap pembelajaran bahasa Indonesia, dalam hal ini siswa sebagai responden dan waktu yang disediakan bagi respoden untuk menjawab adalah 2 x 40 menit.

\subsection{Teknik Analisis Data}

Teknik analisis yang digunakan untuk menilai sikap siswa adalah dengan menghitung rata-rata jawaban berdasakan skor setiap jawaban dari responden.

Untuk menentukan persentase sikap siswa terehadap pembelajaran bahasa Indonesia melalui hasil jawaban angket yang diberikan, dapat dihitung dengan rumus sebagai berikut

$$
\mathrm{P}=\frac{T}{S} \times 100 \%
$$

(Sugoyono: Metode Penelitian Kuantitatif Kualitatif dan $R \& D$. 2011)

Keterangan :

$\mathrm{P}=$ Hasil persentase

$\mathrm{T}=$ Total skor

$\mathrm{S}=$ Skor tertinggi

\subsection{Pengolahan Data}

Data yang telah terkumpul selanjutnya dilakukan pengolahan data. Tahap pengolahannya adalah sebagai berikut.

\subsubsection{Seleksi Data}

Seleksi data yang dimaksud dalam penelitian ini adalah data tentang sikap siswa terhadap pembelajaran bahasa Indonesia di kelas VIII SMP Negeri 15 Konsel. 
Seleksi ini dimaksudkan untuk mendapatkan data yang memenuhi syarat pengelolaan dan analisis. Data yang memenuhi syarat adalah data yang lengkap dan benar, yaitu lembar angket yang terdapat :

a. Nama dan kelas

b. Terdapat jawaban

\subsubsection{Koreksi Data dan Penilaian}

Semua data hasil angket tentang sikap siswa terhadap pembelajaran bahasa Indonesia di kelas VIII SMP Negeri 15 Konsel diperiksa untuk dipisahkan kecenderungan sikap siswa pada masing-masing pertanyaan. Setiap pertanyaan disediakan empat kemungkinan jawaban untuk memilih kecenderungan yang paling tepat sesuai dengan apa yang dilihat dan dialami.

\subsubsection{Analisis Data}

Pada bagian ini data dianalisis dengan menghitung rata-rata jawaban berdasakan skor setiap jawaban dari responden.

\section{HASIL DAN PEMBAHASAN}

Dalam bagian ini akan dipaparkan hasil penelitian mengenai sikap siswa terhadap pembelajaran bahasa Indonesia di kelas VIII SMP Negeri 15 Konsel. Deskripsi tentang sikap tersebut meliputi sikap siswa terhadap guru, sikap siswa terhadap diri sendiri, sikap siswa terhadap materi pembelajaran, sikap siswa terhadap metode pembelajaran, dan sikap siswa terhadap media pembelajaran. Analisis statistik bertujuan untuk mengetahui persentase sikap siswa terhadap pembelajaran bahasa Indonesia.

\subsection{Data dan Analisis Data Sikap Siswa terhadap Pembelajaran Bahasa Indonesia di Kelas VIII SMP Negeri 15 Konsel}

Sikap siswa terhadap pembelajaran bahasa Indonesia di kelas VIII SMP Negeri 15 Konsel dapat diketahui melalui skor yang muncul pada masing-masing item/pertanyaan dan melalui hasil observasi. Frekuensi sikap siswa terhadap pembelajaran bahasa Indonesia di kelas VIII SMP Negeri 15 Konsel dapat dijelaskan sebagai berikut.

1. Terdapat 15 item/pertanyaan positif yang berada pada kategori sangat setuju.

Dengan rincian 3 item yang terdapat pada aspek sikap siswa terhadap guru, 3 item yang terdapat pada aspek sikap siswa terhadap diri sendiri, 3 item yang terdapat pada aspek sikap siswa terhadap materi pembelajaran, 3 item yang terdapat pada aspek sikap siswa terhadap metode pembelajaran, dan 3 item yang terdapat pada aspek sikap siswa terhadap media pembelajaran.

2. Terdapat 1 item/pertanyaan negatif yang berada pada kategori tidak setuju.

Dengan rincian 1 item yang terdapat pada aspek sikap siswa terhadap guru.

3. Terdapat 9 item/pertanyaan negatif yang beada pada kategori sangat tidak setuju. Dengan rincian 1 item yang terdapat pada aspek sikap siswa terhadap guru, 2 item yang terdapat pada aspek sikap siswa terhadap diri sendiri, 2 item yang terdapat pada aspek sikap siswa terhadap materi pembelajaran, 2 item yang terdapat pada aspek sikap siswa terhadap metode pembelajaran, dan 2 item yang 
terdapat pada aspek sikap siswa terhadap media pembelajaran.

Berdasarkan pengolahan data dapat dilihat bahwa dari 25 item/pertanyaan terdapat 24 item/pertanyaan (94\%) yang berada pada daerah sangat setuju, 1 item/pertnyaan (4\%) yang berada pada daerah setuju, 0 item/pertanyaan (-) yang berada pada daerah tidak setuju, dan 0 item/pertanyaan (-) yang berada pada daerah sangat tidak setuju.

Sikap siswa terhadap pembelajaran bahasa Indonesia di kelas VIII SMP Negeri 15 Konsel berada pada daerah sangat setuju. Dengan demikian, sikap siswa terhadap pembelajaran bahasa Indonesia adalah sikap positif

\section{PENUTUP}

\subsection{Kesimpulan}

Berdasarkan hasil penelitian dan analisis data yang dilakukan, dapat disimpulkan bahwa dari 25 item/pertanyaan yang diberikan kepada 88 responden terdapat $24(96 \%)$ item yang berada pada kategori sangat setuju dan terdapat 1 (4\%) item yang berada pada kategori setuju dan berdasarkan hasil observasi data mengenai sikap siswa terhadap pembelajaran bahasa Indonesia juga menunjukan sikap sangat setuju. Dengan demikian, siswa kelas VIII SMP Negeri 15 Konsel bersikap positif terhadap pembelajaran bahasa Indonesia

\subsection{Saran}

Berdasarkan hasil penelitian maka saran yang dikemukakan dalam peneliyian ini adalah guru mata pelajaran bahasa Indonesia perlu mempertahankan kemampuan mengajar yang dimiliki sehingga siswa terus bersikap positif terhadap pembelajaraan bahasa Indonesia, siswa kelas VIII SMP Negeri 15 Konsel pertahankan terus semangat dan motivasi belajar yang dimiliki agar selalu bersikap positif terhadap pembelajaran, dan peneltian selanjutnya selain menggunakan angket dan observasi sebaiknya gunakan juga instrument wawancar agar penelitian lebih jelas dan terstruktur. Selain itu, gunakan kamera yang berkualitas baik agar mendapatkan hasil dokumentasi yang volume dan suaranya jelas.

\section{DAFTAR PUSTAKA}

Ana, Haerun. 2011. Perspektif Pembelajaran Bahasa Indonesia. Kendari: FKIP Unhalu.

Aqib, Zainal. 2016. Model-model, Media, dan Strategi Pembelajaran Kontekstual (Inovatif). Bandung: Yrama Widya.

Arifin, Zainal. 2016. Evaluasi Pembelajaran. Bandung : PT Remana Rosdakarya.

Asmani, Jamal Ma'mur. 2009. Tips Menjadi Guru Inspiratif, Kreatif, dan Inovatif. Jogyakarta: DIVA Press.

Asril, Zainal. 2015. Micro Teaching : Disertasi dengan Pedoman Pengalaman Lapangan. Jakarta: PT Raja Grafindo Persada.

Departemen Pendidikan Nasional. 2008. Kamus Besar Bahasa Indonesia. Jakarta: PT Gramedia Jakarta Utama.

Donsu, Jenita Doli Tine. 2017. Psikologi Keperawatan.

Yogyakarta: Pustaka Baru Press

Husamah dan Yunar Setyanigrum. 2013. Desain Pembelajaran Berbasis Pencapaian Kompetensi - Panduan dalam Merancang Pembelajaran untuk Mendukung Implementasi Kurikulum 2013. Jakarta : Prestasi Pustaka. 
Jihad, Asep \& Abdul Haris. 2013. Evaluasi Pembelajaran. Yogyakarta: Multi Pressindo.

Kurniasih, Imas \& Berlian Sani. 2017. Sukses Mengajar : Panduan lengkap Menjadi Guru Kreatif dan Inovatif. Jakarta : Pustaka Diantara

Suardi, Moh. 2018. Belajar dan Pembelajaran. Yogyakarta : Deepublish.

Yamin, Martimis dan Bansu L, Ansari. 2009. Taktik Mengembangkan Kemampuan Individual Siswa. Jakarta: Gaung Persada press.

Yusuf, Syamsu dan Nani M. Sugandhi. 2016. Perkembangan Peseta Didik : Mata Kuliah Dasar Profesi (MKDP) bagi para Mahasiswa Calon Guru di Lembaga Pendidikan Tenaga Kependidikan (LPTK). Jakarta : PT Rajagrafindo Persada. 